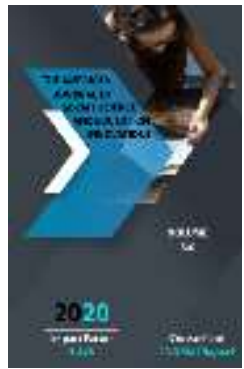

\section{Medieval Scientists Of The Oasis Shash And Their Contribution To Islamic Civilization}

\author{
Nematullo Mukhamedov \\ Doctor Of Historical Sciences, Department History And Source Studies Of Islam - IRCICA, \\ International Islamic Academy Of Uzbekistan
}

Journal Website: http://usajournalshub.c om/index,php/tajssei

Copyright: Original content from this work may be used under the terms of the creative commons attributes 4.0 licence.

\title{
ABSTRACT
}

In medieval sources Tashkent is called as "Shash". From here originated a large number of scholars, whose activities were closely related with such Islamic sciences as Fiqh, Hadith, and etc. Scholars who were born and have contributed to Islamic teachings with their scientific activities ascribed a title (nisba) of "Shashi" and later on (from XIV century) "Tashkandi". It is the Title, with which became famous such kinds of scholars as Haytham ibn Qulayb Shashi, Kaffal Shashi, Abu Bakr Muhammad ibn Ahmad Shashi, Zangiata, Sheikh Umar Bagistani, Sheikh Khawand Tahur, Khoja Ahrar throughout the Muslim world.

\section{KEYWORDS}

Sash, Tashkent, nisba (title), Shashi, Tashkandi, fiqh (islamic law), hadith (prophet sayings), sufism.

\section{INTRODUCTION}

At a time when there is a growing interest in studying the history and culture of cities that unite representatives of different religions and cultures in the context of globalization, the role of civilization in ensuring social cooperation in the world is growing. The study of the history of the culture of cities and the contribution of scientists to the development of civilization are becoming relevant. Such ancient cities as Bukhara, Samarkand, Nasaf (Karshi), Termez, Khiva, Shash (Tashkent) were famous all over the world and were recognized as centers of development of Islamic civilization and as centers of Islamic culture and science. At US universities, research is being conducted on the history of 
Sufism in Central Asia in the Middle Ages, with the Yassaviya and Naqshbandi tariqas; in the research centers of Great Britain - with the Islamic civilization in Central Asia, in Holland with the history and culture of the Islamic civilization of Central Asia, and it should be noted that special attention is paid to the research of the manuscripts of scientists of the Middle Ages stored in many archives and funds of Europe.

In particular, Tashkent is recognized by the world community as a peaceful, friendly, hospitable city of bread. It also has the status of "Eastern Gate", "Capital of Islamic Culture".

Today, at a time when Tashkent is becoming one of the largest cities in the region and the world, research and study of its culture and history in the middle Ages is becoming a topical issue.

\section{THE MAIN FINDINGS AND RESULTS}

In medieval sources, the city of Tashkent was called Shash. It is from here that many scholars who are closely connected with jurisprudence, hadith, Sufism and other Islamic sciences came. The names of the scholars who were born and worked here, who made a great contribution to the teachings of Islam, were added to the ratio "Shash" or later "Tashkent", and with these names they became known to the whole Muslim world.

It is known that in the middle Ages over 100 scientists in the field of Islamic sciences lived and worked in the Shash oasis. These include Abu Said Haytham ibn Qulayb Shashi (d. 947), known as the authentic muhaddith; Abu Bakr Kaffal Shashi (904-976), who was honored to be called "Hazrat Imam" (Holy Imam), as well as Abu Bakr Muhammad ibn Ahmad Shashi (1038-1114), who was awarded the honorary titles "Fakhr ul-Islam" (Pride of Islam ) and "alImam al-kabir" (Great Imam) [10, 119, 224]. Abu Said Haytham ibn Qulayb Shashi (d. 947) also made a great contribution to the science of hadith. His full name is Abu Said Haytham ibn Qulayb ibn Surayj (in some sources it is given as Shuraikh) ibn Makil Shashi Binkasi Turki Adib. He was born in Binkas, near Shash. Haysam ibn Kulayb Shashi collected hadith and visited many cities of Transoxiana Bukhara, Samarkand, Nasaf, Termez and other cities, as well as outside it. According to the sources, he had a lot of mentors and teachers - more than fifty famous scholars and preachers in the field of hadith studies. The most famous of them are Muhaddis Abu Isa Muhammad Termizi (824-892) - a native of Termez and Abul Hasan Baghavi from Makkah $[11,54-60]$.

The main part of Haytham ibn Qulayb Shashi's activity took place in Bukhara and Samarkand, but in the last years of his life he moved to Shash and died here in 947. Arab medieval authors respectfully wrote about our compatriot, calling him "Imam Shashi" and especially emphasized that he was one of the most famous scholars in the field of hadith studies. The work of Haytham ibn Qulayb "Musnad" (“Musnadi Kabir") ("Big support”) is devoted to the interpretation of hadith and is one of the major works in this area. This manuscript was kept in the library "AzZahiriya" in the Syrian city of Damascus until the very near future, then, it was transferred to the library "Maktabat al-Asad" of the same city.

This manuscript of Imam Shashi is 192 pages long. It was rewritten by a calligrapher named Hafiz Ziya'addin Mukaddasi in Naskh script in 1163. It contains hadiths transmitted by the companions of the prophet. The very title of the book "Musnad" explains the content: it is the basis in the study of hadith. Introducing Muslims to the hadiths of moral content, the 
author gives instructions to them in the faith through hadiths that warn a person against sins and bad deeds - murder, intrigue, backbiting and violence.

The Muhaddis of the Shash oasis in the 9th11th centuries taught and worked in libraries and madrasahs of Muslim cities of the world, conducting scientific research on various aspects of religious sciences. This is often mentioned in Arabic sources [12. 780; 10. 75120].

In the world of Islam, along with the Imams alBukhārī, at-Termizi, Abū Manșūr al-Māturīdī and other numerous scholars who were awarded the title of "Imam", a special place is occupied by Imam Abu Bakr Kaffal Shashi. Contemporaries respectfully called him "Hazrat Imam". His full name is Abu Bakr Muhammad ibn Ali ibn Ismail Kaffal Shashi. In Arabic sources, as a sign of respect and honor, the word "Kabir" is added to his name, meaning "great". Initially, he was a skilled artisan who made locks, and therefore later the word "Kaffal" was added to his name, i.e. "Making locks", "locksmith" [2. 211-283; 10. 119-126]. Imam Kaffal Shashi was born in the city of Tashkent (Shash) in 904, in the family of an ordinary craftsman. He received his first knowledge in his city, then studied in Samarkand, Bukhara, Termez, where he got acquainted with the works of Imam Bukhārī and Imam Termizi.

In search of knowledge, Imam Kaffal Shashi traveled around the countries of the Near and Middle East. He studied with the most prominent scientists of that time in Baghdad, Kufa, Damascus. According to the sources, he studied fiqh under Ibn Surayj. In the field of history, his teacher was Abu Jafar Muhammad ibn Jarir Tabari (died 923), a famous scholar, expert on the Koran (mufassir). Another mentor was the famous theologian Abul Hasan Ali ibn Abi Musa Ash'ari (d. 935).
Arab medieval authors called Kaffal Shashi a great scientist. The famous historian Abu Sa'd Abdulkarim ibn Muhammad Sam'ani in his work Kitab al-Ansab (The Book of Genealogies) wrote about him: "Abu Bakr Muhammad ibn Ali ibn Ismail Kaffal Shashi was from Shash and became famous as a lockmaker. He was the Imam of his time, and was also an irreplaceable and incomparable scholar in such areas of Islamic sciences as fiqh, hadith, foundations of fiqh (usul), linguistics. The name Kaffal Shashi is known both in Maghreb and in Mashrik"[1. 244-245; 10. 119].

Imam Kaffal Shashi is the author of many works. Among his works devoted to the issues of Islamic law (figh), dialectics and the history of Islam and hadith studies, there are: "Jadal al-hasan" ("The beauty and beauty of dialectics"), "Kitab fi usul fiqh" ("Book of the foundations of fiqh"), "Sharh ar-risala" ("Commentary on the work"), "Javami alkalim" ("Collection of wise sayings"), "Adab al-Kazi" ("The behavior of the Kaziy"), "Dalail an-nubuvvat" ("Evidence prophecies"), "Mahasin ash-shari'a"("The delights of the Sharia"). The manuscript of the book "Javami al-Kalim" is kept in the Syrian library "Zahiriya"; a photocopy of this manuscript was brought to Uzbekistan in 1970 by Mufti Ziyauddinhan ibn Ishan Babakhan. Now it is kept in the library of the Main Administration of Muslims in Tashkent. In this work, of an educational and didactic nature, Kaffal Shashi succinctly and succinctly described hadiths ("sahih"), using not only the commandments of Islam, but also sayings related to education, training, enlightenment, human behavior, etc. The book is not devoid of valuable and rare aphorisms that were widely used by people, which in turn ensured a wide and accelerated distribution of hadiths among the masses.

The tomb and complex of Imam Kaffal Shashi is located on the territory of Tashkent, called 
the "Old City" and is a place of worship for Muslims. The people call him "Hastimam" (Hazrat Imam).

Famous as "Fakhr al-Islam" ("Pride of Islam") Abu Bakr Muhammad ibn Ahmad Mustazhiri Shashi (1038-1114) was the leader of the fakikhs of Baghdad, famous in the middle Ages as the center of Islamic culture. He was born and raised in Shash, but studied in Baghdad and studied fiqh under the guidance of such a famous fuqih as Abu Nasr ibn Sabbag. Abu Bakr Muhammad ibn Ahmad Shashi became a close disciple of the Baghdad sheikh Abu Ishak Shirazi (d. 1083) and attained the rank of Imam Kabir (Great Imam). He penned many books on fiqh issues. Among them, for example, a book written by order of the Abbasid caliph Mustazhir (d. 1119) "Khilyat ulama fi mazahibi fuqaha"("Decoration of scientists in the currents of fakikhs") about the ethics of fakikhs and qazis. Thanks to this work, Abu Bakr Shashi acquired the title of "Mustazhiri" - "close to the Caliph Mustazhir." In many subsequent sources, he is mentioned in this way [13. 341, etc.].

Abu Bakr Shashi had deep knowledge in the field of Arabic literature, language and poetry. He died in Baghdad. His grave is located next to the tomb of his teacher - Sheikh Abu Ishak Shirazi in "Bab Shiraz".

The Mongol invasion led to a decline in the social and cultural life of the peoples of Central Asia. The national liberation struggle was supported by spiritual and religious principles, in particular, by the activities of the Sufi brotherhoods. At this time, such tariqas were formed in Islam such as Kubraviya, Naqshbandiya.

Sufism during this period became a unifying force in the spiritual life of the peoples of Central Asia. One of the representatives of the Sufi leaders (sheikhs) was Zangiata. His real name is Aykhoja ibn Tashkhoja. Zangiata was born in the Samarkand Darboza mahalla in the city of Tashkent. Because of his dark skin color and generosity, he was nicknamed "Zangiata Himmati" ("Generous Zangiata") [6, 3].

The whole life of Zangiata coincided with a period of instability and violence in Transoxiana caused by the invasion of the Mongols. In these difficult times, Zangiata and about ten of his disciples, through their efforts and efforts, spiritually supported the people, nourished them with noble universal human values, such as: courage, patriotism, hard work, honesty, justice, disinterestedness, kindness, a righteous lifestyle and mercy.

It should be especially noted that the great Amir Temur was one of those outstanding personalities who showed worthy respect to the memory of the righteous Sufi sheikhs. He paid great attention to the construction of mausoleums, mosques and khanaqahs. Such good deeds of Amir Temur left their mark in the Tashkent oasis. The complex of mausoleums, consisting of the tombs of one of the famous followers of Sheikh Zainiddin, Zangiota and his wife Anbar Bibi, was built under the patronage of Amir Temur.

One of the representatives of Sufism was Sheikh Umar Vali Bagistani [14. 123-130; 270272]. He was born in the village of Bagistan, Tashkent region. The date of his birth is unknown, but he died in 691/1291. He led a modest life, honestly earning a living from agriculture and gardening, setting an example for others. Despite the fact that he was one of the prominent Sufis, he did not pursue fame. He strove to be simple, but at the same time a real person, this can be seen in one of his instructions to his son Sheikh Khavandi Tahur. This instruction is given in the book by Fakhraddin Ali Safi "Rashakhat": "Tahur, don't be a mullah (theologian), don't be a Sufi, don't be this, don't be that, but be a Muslim" [15. 29-33; 271].

Sheikh Khavandi Takhur [4, 53] (died 1355), the son of Sheikh Umar Bagistani, who was 
respected by Baha-ud-Din Naqshband himself, was born in the village of Bagistan, Tashkent region [8. 116; 14. 123-130]. Thanks to his knowledge, he enjoyed great authority in the Muslim world [9, 5].

Sheikh Khavandi Takhur's mausoleum has become a sacred place for Muslims. In the second half of the 15th century, his greatgrandson Khoja Akhrar ordered to build a tomb over his grave [7, 5, 14; 15, 29-33], which is now located on the territory of the Tashkent Islamic University (since 2018 - the International Islamic Academy of Uzbekistan). Khoja Ubaydallah Akhrar was one of the most authoritative Islamic leaders of Maverannahr. $\mathrm{He}$, too, was from the village of Bagistan, Tashkent region, where he was born in the month of Ramadan (March 1404). His father Haji Mahmud and grandfather were educated people, engaged in agriculture and trade. His mother was the daughter of Haji Dawood, the son of Sheikh Khavandi Takhur [5, 62, 218-219, 13].

Hajja Ubaydullah Akhrar was the largest representative of the Naqshbandiyya tariqah. He has earned respect throughout the Islamic world. Widely promoting the famous saying of Bahauddin Naqshbandi "Dil ba yoru, dast ba kor" (May your heart be with Allah, and your hands in labor), with his peacemaking and religious activities he won high prestige among the people, for which he was awarded the title of "wali" ( awliya, "holy"). Only three works of Haji Akhrar have survived to our time. "Fakarat ul-arifin" ("Excerpts from the words of arifs") is a book in which he tells about several representatives of Sufism and gives examples from their sayings, the second work "Validiyya" ("Dedication to the Father") contains explanations of the concepts and norms of moral behavior a person who entered this teaching. The work was translated by Zakhiriddin Muhammad Babur from Persian into Uzbek in poetic form. The third work "Khavraiya" is devoted to the commentary of the rubaiyat of the famous Sufi poet Abu Said Abulkhair, beginning with the word "Khavro" ("Angels").

In addition, several letters (ruk'aname) of the Sheikh have reached us, addressed to contemporaries and collected together by Alisher Nava'i in a collection called by him "Majmuai murasalat". It should be mentioned here that Professor A. Urinbaev with Professor of the University of New Jersey Joe Ann Gross published the book "Letters of Haji Ubaidall Ahrar and his Murid Students" in the Dutch publishing house "Brill" in 2002 in English.

It should be noted that the oasis and the city of Tashkent is an abundant, flourishing land, rooted in the distant past. Khorezm, Sogdiana, Fergana, Shash oasis are the regions located along the Great Silk Road, connecting the countries of the West and the East. Therefore, they were developed, economically and culturally, regions. In turn, Shash (in some sources (hach) was also a major cultural center. The fact that medieval Shash was one of the major cultural Islamic centers of Central Asia is proved by the analysis of historical information about the activities of scientists of Islamic sciences.

\section{CONCLUSION}

To sum up, we can conclude that in the late 9th - early 10th centuries Tashkent became a major center for the development of Islamic spirituality and culture. Here, as in the central regions of the Caliphate, the rise of spirituality took place [3. 42]. Starting from the 10th century, the first mausoleums began to be built here in the burial places of famous religious figures - sheikhs and imams, who spread Islam, whose religious activities and life paths are directly connected with Tashkent. 
History shows that the spiritual, scientific and cultural potential of medieval Tashkent was very high and this city has always been one of the centers not only of Central Asia, but of the entire Muslim world.

\section{REFERENCES}

1. Abu Sa'd Abdulkarim ibn Muhammad Sam'ani. al-Ansob. Tashkent: 7. -pp. 244245.

2. Abu Sa'd Abdulkarim ibn Muhammad as Sam'ani. alansob. Bayrut: 1980. 82. 10vol. p. 211; see Shamsuddin al-Zahabi. Siyar alam annubala. Bayrut: Muassat Arrisala. 16vol. -p. 283; see Prozorov S. Al-Kaffal // Islam in the territory of the former Russian Empire. Encyclopedic Dictionary. Moscow: Eastern Literature, 2000. Issue. 2.-p. 46; Lykoshin N. Remember the first teacher // People's University. 1918, No. 9. -p. 1; Tojuddin al-Subki. Ashshafiyya alcubra tobacco. Beirut: Dar Alkutub Alilmiya, 1999.3vol. -p. 152.

3. Alimova D; Filanovich M. Tashkent at the turn of eras // History of Tashkent (from ancient times to the present day). Tashkent: ART FLEX. 2009. -p.160.

4. Valikhjayev B. Shaikh Khovand Taqur // Mulot. 1998. 2-dormouse. -p. 53.

5. Valikhjayev B. History of Hoja Ahror. Tashkent: Writer. 1994. -p. 62; sm.Rashaxat. Izd. Lakxnav. -p.218-219; Karimov E. The life and work of Hodja Ahror. Tashkent: Manaviyat. 2003. -p.13.

6. Zangiota Chemistry / Prep. to ed. Fayziev Turgun. Tashkent: Transoxiana. 2001. -p. 3. Mukhamedov N. Zangi ata memorial complex - as a center of Islamic culture in Central Asia // Science, Research, Development No. 15. Monografia Pokonferencyjna. Rotterdam (The Netherlands), 2019. -pp.105-109. ttp: //xn-- e1aajfpcds8ay4h.com.ua/files/87_05_2_v. pdf

7. Islomov Z; Maqsudov D. Sheikh Khovand Tahur Memorial Complex. Tashkent: Tashkent Islamic University. 2005. -p. 5.

8. Masson M. The past of Tashkent. Tashkent: Iz-in of the Academy of Sciences of the UzSSR. 1954. No. 2. -p. 116.

9. Mahmud Kasaniy, Karomat Kilicheva. Shaikh Khovandi Takhur. Tashkent: 2004. -p. 5.

10. Muhamedov, N. Keffal Shashi's diplomatic activity. Marmara Turkish Studies Journal 2 (2), 119-126. https://dergipark.org.tr/tr/download/articl e-file/282071. Mukhamedov Nematullo (2020) "Activities of Hadith Scholars (Muhaddis) of Shash Oasis in Scientific Centers of the Region". The Light of Islam: Vol. 2020: Iss.2, Article 11. Available at:

https://uzjournals.edu.uz/iiau/vol2020/iss2 /11. Muxamedov N. The role of Shosh oasis scientists in Central Asian science and culture. Monograph. Tashkent: Transoxiana. 2011. -p. 224.

11. Mukhamedov N; Turambetov N. Memorial complex of the Sultan Uwais Baba - one of cult historical centers in Central Asia // Academicia: An International Multidisciplinary Research Journal (Double Blind Refereed \& Reviewed International Journal) Vol. 10 Issue 6, June 2020 Impact Factor: SJIF 2020. $7.13 \mathrm{http}: / / w w w . s a a r j . c o m$. Muxamedov N. The role of Shosh oasis scientists in Central Asian science and culture. Monograph. Tashkent: Transoxiana, 2011. -p. 54-60; Abu Sa'id alHaytham ibn Kulayb ash-Shashi. alMusnad. -Madinai munawwara: Maktabat al-ulum val-hikam, 1990. Volume 1. -pp.1417. 
12. Tajuddin Abu Nasr Abdulvahab al Ashshafiyya alcubra tobacco. Beirut: Dar alqutub alilmiya. 1999.3vol. -p. 341; Shamsuddin al-Zahabi. Siyar alam annubala. 19vol. S. 393; Rizauddin Fakhriddin. Imom Gazzali. Institute of Oriental Studies of the Academy of Sciences of the Republic of Uzbekistan named after Abu Raikhan Beruni. Inv. No. 9122. - p.16.

13. Mukhamedov Nematullo. (2019) "The role of the Sheikh Zayniddin complex in the spiritual life of Tashkent" // Multidisciplinary scientific journal "Arhivarius" collection of scientific publications. -pp.7-14. https://www.researchgate.net/publicatio n/333985613. Mukhamedov Nematullo. Stripes Of Sheikh Umar Baghistany /I Asian Journal of Research (Japan Osaka) 1 (№ 5, 2017), - pp. 123-130. www.journalofresearch.asia info@journalofresearch.asia (Japan Osaka). Fakhruddin Ali Safiy. Rashakhot / Prep. to ed. Mahmud Hasaniy, Bahriddin Umrzok. Tashkent: Abu Ali ibn Sino, 2004. -pp. 270-272.

14. Mukhamedov N. A. (2019). The Role of the Memorial Complex of Sheikh Hovand Tahur in Islamic Culture of the Region. The Light of Islam: Vol. 2019: Iss. 1, Article 3. Available at: https://uzjournals. edu.uz/cgi/viewcontent.cgi?article $=1026 \&$ context=iiau. Fakhruddin Ali Safiy. Rashakhot / Prep. to ed. Mahmud Hasaniy, Bahriddin Umrzok. Tashkent: Abu Ali ibn Sino, 2004. -p. 271.

15. DeWeese, Devine. Yasavian legends on the islamization of Turkistan. Aspekts of Altaic Civilization - III. Proceeding of the Thirten Meeting of the Permanent International Altaistic conference Indiana University (in) 1987. Ed. D. Sinor. Bloomington, 1990, -pp. 1-19.
16. Medieval Islamic Civilization Josef W. Meri Routledge encyclopedias of the Middle Ages. Tом I. Psychology Press, 2006. -p. 933.

17. Medieval Central Asia and the Persianate World: Iranian Tradition and Islamic Civilisation. British Institute of Persian Studies Series. London: I. B. Tauris, 2015, pp. 1-12. 